\title{
Atypical bovine interstitial pneumonia in a semi-intensive beef cattle system
}

\author{
Ana Carolina Barreto Coelho ${ }^{1}$ Plínio Aguiar Oliveira ${ }^{2}$ Bianca Lemos dos Santos ${ }^{1}$ \\ Pablo Estima-Silva ${ }^{1}$ Haide Valeska Scheid ${ }^{2}$ Sofia del Carmen Bonilla de Souza Leal ${ }^{3}$ \\ Clairton Marcolongo-Pereira ${ }^{4}$ Ana Lucia Schild ${ }^{5^{*}}$
}

\footnotetext{
${ }^{1}$ Programa de Pós-graduação em Veterinária, Faculdade de Veterinária, Universidade Federal de Pelotas (UFPel), Capão do Leão, RS, Brasil. ${ }^{2}$ Programa de Pós-graduação em Parasitologia, Instituto de Biologia (IB), Universidade Federal de Pelotas (UFPel), Capão do Leão, RS, Brasil. ${ }^{3}$ Médica Veterinária Particular.

${ }^{4}$ Faculdade de Veterinária, Centro Universitário Ritter dos Reis (UniRitter), Alto Teresópolis, Porto Alegre, RS, Brasil.

${ }^{5}$ Laboratório Regional de Diagnóstico, Faculdade de Veterinária, Universidade Federal de Pelotas (UFPel), Campus Capão do Leão, s/n, 96015-560, Capão do Leão, RS, Brasil. E-mail: alschild@terra.com.br. "Corresponding author.
}

\begin{abstract}
The aim of the present study was to describe an outbreak of atypical interstitial pneumonia affecting 15 Angus cattle aged 7-30 months in the south of Rio Grande do Sul. The clinical course of the disease was approximately 1-3 days. The cattle were kept in the native field and had received feed containing the remains of wafers from a food factory before the outbreak. Clinical signs included dyspnea and abdominal breathing, with a clinical evolution period of up to 3 days. Nine animals presented apathy and respiratory difficulty and died within 24h, while three animals exhibited a clinical evolution period of 36-48h. Three other animals died without any clinical signs. The main macroscopic lesions were observed in the lungs, which did not collapse at the opening of the thoracic cavity and showed a rubbery consistency. On the cut surface, the organs were firm and dark red, with marked distension of the interlobular septa due to edema. Histopathological analysis revealed thickening of the interlobular pulmonary septa; interstitial edema and emphysema; mild mononuclear cell, eosinophil, and neutrophil infiltration; areas of type II pneumocyte proliferation, and thickening of the alveolar walls. Fibrin was observed in the alveolar lumen with the formation of hyaline membranes. On the basis of macroscopic and histological examinations and epidemiological data, a final diagnosis of atypical interstitial pneumonia was made. Although, the cause of the disease has not been identified, it is believed that the bran wafer meal contained ingredients that were not suitable for animals, consequently triggering the disease.

Key words: pulmonary edema, emphysema, respiratory disorder, cattle, hypersensitivity, interstitial pneumonia.
\end{abstract}

Pneumonia intersticial atípica em bovinos de corte criados em semi confinamento

RESUMO: Descreve-se um surto de pneumonia intersticial atípica diagnosticado no Sul do Rio Grande do Sul, afetando 15 bovinos da raça Angus, entre 7 e 30 meses de idade, de um total de 400 animais. Os bovinos estavam em campo nativo e recebiam farelo de bolacha proveniente de uma fábrica de produtos alimentícios. Os sinais clínicos caracterizaram-se por dispneia e respiração abdominal. Nove animais apresentaram apatia e dificuldade respiratória morrendo em 24 horas, em três bovinos a evolução clínica foi de 36 a 48 horas e outros três morreram sem observação de qualquer sinal clínico. As principais lesões macroscópicas foram observadas nos pulmões, que não colapsavam na abertura da cavidade torácica e apresentavam consistência elástica. Na superficie de corte o órgão era firme e vermelho escuro com acentuada distensão dos septos interlobares e interlobulares por edema. Histologicamente, havia espessamento dos septos interlobulares pulmonares, edema e enfisema intersticial, infiltrado inflamatório discreto de células mononucleares, eosinófilos e neutrófilos, áreas de proliferação de pneumócitos tipo II e espessamento das paredes alveolares. Havia fibrina na luz alveolar e formação de membranas hialinas. As lesões macroscópicas e histológicas, associadas aos dados epidemiológicos, permitiram o diagnóstico de pneumonia intersticial atípica. Apesar de não ter sido identificada a causa da enfermidade acredita-se que o farelo de bolacha, com ingredientes não adequados a alimentação animal e em forma de farelo, possa ter desencadeado a doença.

Palavra-chave: edema e enfisema pulmonar, distúrbio respiratório, bovinos, hipersensibilidade, pneumonia intersticial.

Atypical interstitial pneumonia (PIA) is described as an acute respiratory syndrome that affects cattle, generally above 2 years of age, and is characterized by edema and pulmonary emphysema
(DOSTER, 2010). It is a noncontagious and metabolic disease, with 3-methylindole (3-MI) implicated as a causative agent. Other associated factors include food additives, fungi, parasites, pneumotoxic substances, 
thermal stress, viral pneumonia, bacterial infection, irritating gases, and hypersensitivity reactions (RAVIOLO et al., 2007b; DOSTER, 2010).

PIA can occur in hyperacute, acute, and chronic forms. In acute cases, the primary clinical signs include dyspnea and respiration with the neck extended and the mouth open (WICPOLT et al., 2014). Chronic PIA occurs in animals who recover from acute conditions and present with progressive respiratory distress (RAVIOLO et al., 2007a). The morbidity rate may range from $30 \%$ to $50 \%$; although, the mortality rate is generally low at $5 \%$ 10\% (DOSTER, 2010).

The aim of the present study was to describe a PIA outbreak in a semi-intensive beef cattle production system in southern Brazil, evaluate the epidemiological aspects and pathology of the disease, and discuss the possible causes and differential diagnoses.

In May 2016, a bovine from a farm in southern Brazil, where seven bovines had suddenly died or exhibited discrete respiratory signs, was sent for necropsy. Subsequently, seven other bovines with similar signs were necropsied on the farm. From 400 Angus cattle housed in the native field and divided in different groups of 20 to 60 animals each, 15 animals aged 7-30 months were affected. Epidemiological and clinical data were obtained from the veterinarian responsible for the animals. Fragments of all organs were fixed in $10 \%$ buffered formalin, routinely processed, and stained with hematoxylin and eosin. Fragments of the lungs, fluid samples from the thoracic cavity, and tracheal swabs were sent for microbiological culture; tracheal wash samples from cattle with clinical respiratory signs were referred for viral isolation in cell culture; and samples of the feed administered to the animals were sent for fungal culture.

Approximately 10 days before the first death, the cattle had received, ad libitum, feed comprising biscuit bran from a food factory mixed with an unspecified amount of barley radicle. The bran was crushed and kept in small quantities in plastic containers in an enclosed environment and was renewed weekly. Nine affected cattle presented apathy and respiratory difficulty and died within $24 \mathrm{~h}$. In three cattle, the clinical evolution period was 36-48h. Three cattle died suddenly without clinical manifestations. Two animals were breathing with their mouths open and tongue exposed. Morbidity rate was $3.94 \%$ and the lethality rate was $100 \%$. A group of 20 cattle that did not receive the wafer bran remained unaffected. Furthermore, after removal of the wafer bran from the feed, new cases were not observed.
Necropsy of the eight affected cattle revealed similar lesions characterized by the presence of white foamy contents in the trachea and suffusions in the larynx and trachea. The lungs did not collapse at the opening of the thoracic cavity and exhibited a rubbery consistency. On the cut surface, the lungs were dark red and firm, with marked distension of the interlobular septa due to edema (Figure 1A and B). The liver exhibited an accentuated lobular pattern. Moderate to severe edema was observed in the subcutaneous tissue of the ventral neck and the mesentery in three animals.

Microscopic examinations revealed thickening of the interlobular pulmonary septa due to edema and interstitial edema and emphysema. Alveolar walls were thickened by discrete infiltration of mononuclear cells, eosinophils, and neutrophils. Areas of type II pneumocyte proliferation were observed. Fibrin in the alveolar lumen and hyaline membranes were also observed (Figure 1C and D). Culture of the tissue fragments and secretions revealed no bacterial growth. No fungi were isolated from the wafer meal given to the animals, and no viruses were identified in the cell cultures.

A final diagnosis of PIA was made on the basis of the clinical signs and macroscopic and histological findings, which were similar to those described by other authors in different reports of the disease (FIGHERA et al., 2003; RAVIOLO et al., 2007a; RAVIOLO et al., 2007b; WICPOLT et al., 2014). In the bovines evaluated in this investigation, PIA was believed to have occurred as a consequence of ingestion of wafer meal, which was easily inhaled by the cattle in its crushed state to result in a hypersensitivity reaction in the pulmonary airways. In addition, the presence of substances such as chemical additives and preservatives, which are always present in industrialized foods, may have triggered a hypersensitivity reaction, which causes free radicalmediated endothelial injury that leads to increased vascular permeability with consequent edema and extravasation of fluid and protein for alveolar lumen (KOBZIK, 1999). Another fact suggesting that the wafer meal was the cause of PIA is that 20 animals that did not receive this food remained healthy. Morbidity rate in this outbreak was 3.94\%. Other authors have reported a variable morbidity rate between $30 \%$ and 50\% (RAVIOLO et al., 2007a). The low morbidity rate in the present investigation can be attributed to prompt elimination of the wafer meal from the feed of the animals following suspicion of its involvement in the pathogenesis of the disease. The macroscopic and histological findings in this investigation were 

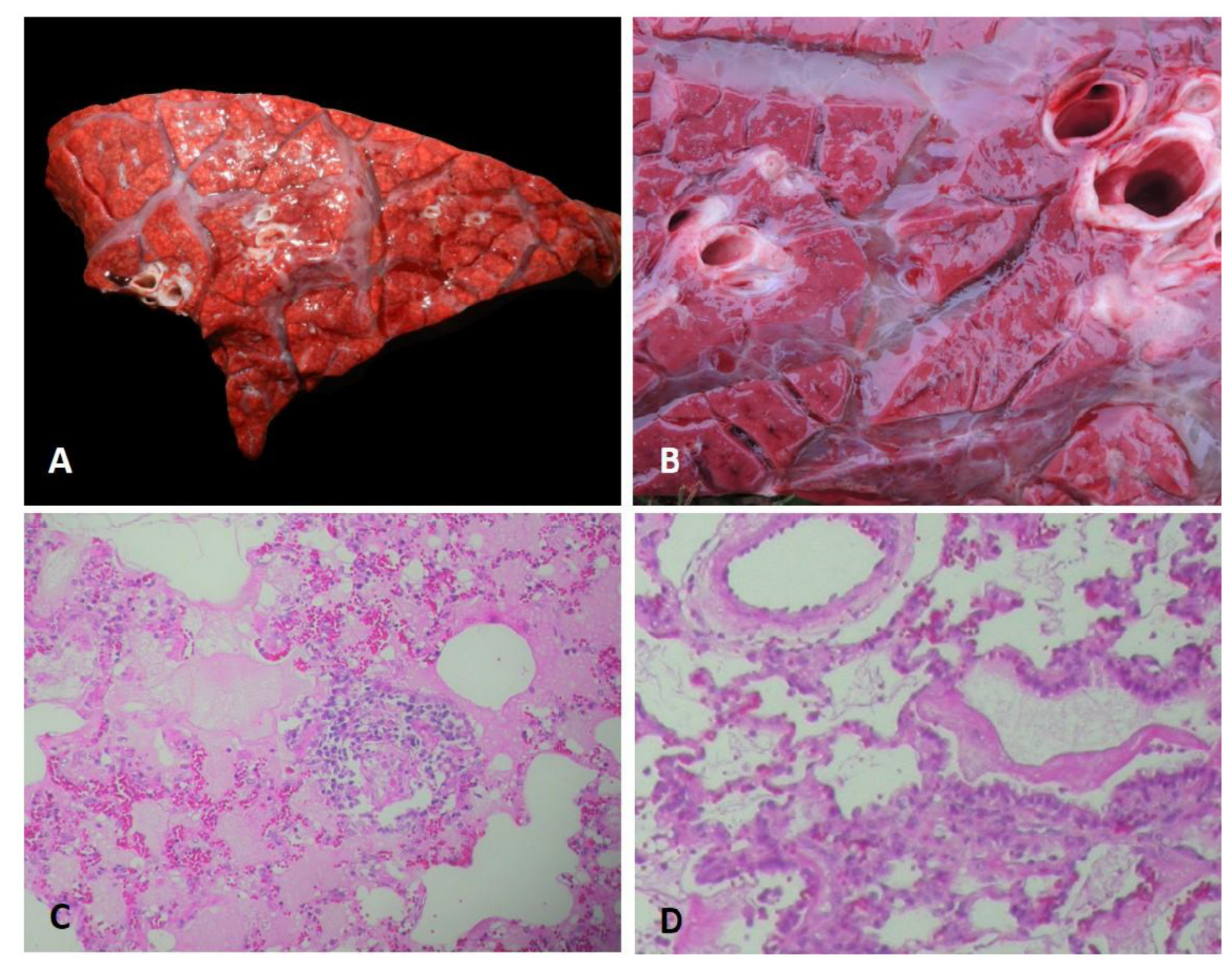

Figure 1 - Atypical interstitial pneumonia in cattle. A. Cut surface of the lung of cattle with edema and emphysema B. There is marked distension of the interlobular septa by whitish gelatinous material. C. Lung with edema, emphysema and discrete inflammatory infiltrate in the interstitium. HE 20X. D. Lung with presence of hyaline membranes and hyperplasia of type II pneumocytes. HE 40X.

also similar to those described in other studies on PIA (FIGHERA et al., 2003; WICPOLT et al., 2014).

With regard to differential diagnoses for PIA, respiratory diseases that occur in acute or subacute outbreaks should be considered (KERR et al., 1989). Enzootic pneumonia is an infectious disease that primarily occurs in beef calves and dairy calves raised in intensive production systems (ASSIS-BRASIL et al., 2013). Bovine respiratory syncytial virus (BRSV) causes enzootic pneumonia and can produce synergistic effects with 3-MI when both are present in an animal (RAVIOLO et al., 2007b). In the present investigation, there were no lesions compatible with those observed in enzootic pneumonia, and there was no viral growth in the cell cultures. PIA may also be associated with the ingestion of moldy sweet potato, which produces several toxins capable of causing lung injury (FIGHERA et al., 2003). Furthermore, reinfection by large numbers of Dictiocaulus sp. larvae in sensitized animals may produce a reaction that causes acute pulmonary emphysema (RAVIOLO et al., 2007a). Cattle investigated here did not receive sweet potatoes, and larvae of parasites were not observed in the lungs. It is unlikely that the disease was caused by grazing, because a group of 20 cattle kept in the same area remained healthy. Other studies on PIA have reported that the relocation of cattle from a low-quality pasture to an exuberant pasture can trigger disease (WICPOLT et al., 2014); this was not the case for the animals in the present investigation.

In conclusion, PIA in the cattle assessed in this study was caused by the ingestion of a wafer meal containing ingredients that were not suitable for animal consumption. Furthermore, because this food was crushed and powdered, it probably led to a hypersensitivity reaction that triggered the disease. 


\section{REFERENCES}

ASSIS-BRASIL, N. et al. Respiratory diseases in calves in southern Rio Grande do Sul: study of 33 outbreaks. Pesquisa Veterinária Brasileira, v.33, n.6, p.745-751, 2013. Available from: <http://dx.doi.org/10.1590/S0100736X2013000600010>. Accessed: Mar. 02, 2017. doi: 10.1590/ S0100-736X2013000600010.

DOSTER, A.R. Bovine atypical interstitial pneumonia Veterinary Clinical Food Animal, v.26, p.395-407, 2010. Available from: <https:/www.google.com.br/\#q=doi:10.1016/j. cvfa.2010.03.002>. Accessed: Apr. 10, 2017. doi: 10.1016/j. cvfa.2010.03.002.

FIGHERA, R.A. et al. Interstitial pneumonia in cattle fed moldy sweet potatoes (Ipomoea batatas). Pesquisa Veterinária Brasileira, v.23, n.4, p.161-166, 2003. Available from: <http:// dx.doi.org/10.1590/S0100-736X2003000400004>. Accessed: Mar. 01, 2017. doi: 10.1590/S0100-736X2003000400004.

KERR, L.A., et al. A review of interstitial pneumonia in cattle. Veterinary and Human Toxicology, v.31, n.3, p.247-254, 1989. Available from: <http://europepmc.org/abstract/med/2662572>. Accessed: Mar. 08, 2017.
KOBZIK L. The lung. In: CONTRAN R.S. et al. (Eds.). Robbins - pathologic basis of disease. 6.ed. Philapelphia: Saunders, 1999. 1425p. p.697-755.

RADOSTITS, O.M. et al. Veterinary Medicine: A textbook of the diseases of cattle, horses, sheep, pigs and goats. $10^{\text {th }}$ ed. Saunders LTD., 2007. 2065p.

RAVIOLO, J. et al. Description of an acute bovine pulmonary edema and emphysema outbreak in southwest Cordoba, Argentina. Técnica Pecuária en México, v.45, n.1, p.111-120, 2007a. Available from: <http:// www.redalyc.org/articulo.oa?id=61345110>. Accessed: Dec. 12, 2016.

RAVIOLO, J. et al. Neumonía intersticial atípica en bovinos engordados a corral. Enfermedades de los bovinos en feedlot. Sitio Argentino de Producción Animal. v.108, n.1, p.1-5, 2007b. Available from: <http://www.produccion-animal.com.ar/sanidad intoxicaciones_metabolicos/enfermedades_en_feedlot/01-NIA_ Feed lot.pdf>. Accessed: Dec. 07, 2016. (Electronic publication).

WICPOLT, N.S. et al. Acute pulmonary edema and emphysema in cattle in Southern Brazil: spontaneous disease and experimental reproduction. Pesquisa Veterinária Brasileira, v.34, n.12, p.1167-1172, 2014. Available from: $<$ http://dx.doi.org/10.1590/S0100-736X2014001200004>. Accessed: Dec. 21, 2016. doi: 10.1590/S0100-736X2014001200004. 